\title{
Somatotype Profile of a Special Police Unit
}

\author{
Perfil de Somatotipo de una Unidad Especial de Policía
}

\author{
Jozef Simenko
}

\begin{abstract}
SIMENKO, J. Somatotype profile of a special police unit. Int. J. Morphol., 36(4):1225-1228, 2018.
SUMMARY: The purpose of this research was to investigate the somatotype characteristics police special units to give us a better idea about requirements of body composition and somatotype for training or/and selection process of new candidates. Therefore, an anthropometric analysis was conducted on 17 male members of Slovenian special police unit with mean age $31.12 \pm 5.61$ years, body height $179.46 \pm 5.36 \mathrm{~cm}$ and body weight $79.84 \pm 6.16 \mathrm{~kg}$. They were assessed with anthropometric variables in accordance with ISAK. The following measurements were taken: upper arm circumference, flexed upper arm circumference, forearm circumference, thigh circumference, mid-thigh circumference, calf circumference, shoulder width, pelvic width, elbow diameter, wrist diameter, knee diameter, ankle diameter, sub scapular skin fold, triceps skin fold, biceps skin fold, forearm skin fold, abdomen skin fold, chest skin fold, supraspinale skin fold, thigh skin fold and calf skin fold. Also, the bioelectrical impedance TANITA TBF-105 was used for measurements of body weight, body mass index, lean body mass, the percentage of fat mass, absolute fat mass and the percentage of body water were measured. Somatotype components and the position in the somatoplot was calculated with the Somatotype 1.2.5. software. The values found in this study indicate a significant importance of mesomorph component for police special units and their nature of work with dominance of balanced mesomorph somatotype (2.59-6.49-1.98).
\end{abstract}

KEY WORDS: Morphology; Anthropometry; Tactical officers.

\section{INTRODUCTIÓN}

Special police units are top-level police units that, with their mobility, adapted tactics and modern equipment, solve the most demanding security tasks (Gorenak et al., 2007). Therefore, maintaining a high level of physical and operational preparedness is essential for the rapid, coordinated and tactical operation of special units. Police officers who are physically well prepared and have adequate morphological status are less prone to diseases in the workplace are more productive and better tolerate stress (Zorec, 2009; Yao et al., 2016), therefore morphological requirements for special police units should be even higher in comparison to regular police officers. One of the most used methods of evaluation of morphological status is anthropometry (Claessens et al., 2000; Malina, 2007; Slater et al., 2013; Rodrigues-Ferreira et al., 2015) with its somatotype description. Somatotype as a method describes and expresses the quantification of three components relative to height: 1) endomorphy, which express body fat content, 2) mesomorphy, which express the development of skeletal muscle and 3) ectomorphy, which express the thinness of the body (Carter \& Heath, 1990; Ochoa Martínez et al., 2014).
There is a scarcity of studies that evaluate the somatotype of special police units. Therefore, the aim of this study is to investigate the somatotype characteristics of this population to give us a better idea about requirements of body composition and somatotype for training or/and selection process of new candidates.

\section{MATERIAL AND METHOD}

Subjects. This study included 17 members of Slovenian special police unit. Their mean age was $31.12 \pm 5.61$ years, their body height $179.46 \pm 5.36 \mathrm{~cm}$, and their body weight was $79.84 \pm 6.16 \mathrm{~kg}$. Written informed consent was obtained from all participants.

Anthropometric measurements. Measurements were conducted in the physiological laboratory at Faculty of Sport, University of Ljubljana. Morphologicalcharacteristics were measured by anthropometry methods and by electrical bioimpedance. GPM Swiss measurement instruments were used 
for the anthropometry method. Measurements were carried out by an expert with extensive experience, following the prescribed procedures and guidelines set by the International Society for Advancement of Kinanthropometry (ISAK) with a technical error of measurement less or equal to $1 \%(\mathrm{~cm})$.

The following measurements were taken: upper arm circumference $(\mathrm{cm})$, flexed upper arm circumference $(\mathrm{cm})$, forearm circumference $(\mathrm{cm})$, thigh circumference $(\mathrm{cm})$, midthigh circumference $(\mathrm{cm})$, calf circumference $(\mathrm{cm})$, shoulder width $(\mathrm{cm})$, pelvic width $(\mathrm{cm})$, elbow diameter $(\mathrm{cm})$, wrist diameter $(\mathrm{cm})$, knee diameter $(\mathrm{cm})$, ankle diameter $(\mathrm{cm})$, sub scapular skin fold ( $\mathrm{mm})$, triceps skin fold ( $\mathrm{mm})$, biceps skin fold ( $\mathrm{mm}$ ), forearm skin fold ( $\mathrm{mm}$ ), abdomen skin fold $(\mathrm{mm})$, chest skin fold (mm), supraspinale skin fold ( $\mathrm{mm})$, thigh skin fold $(\mathrm{mm})$, and calf skin fold $(\mathrm{mm})$. According to the Heath-Carter method (Carter \& Heath) we calculated proportions of ectomorph, mesomorph, and endomorph components. Somatotype attitudinal distance (SAD) and the position in the somatoplot was calculated with the Somatotype 1.2.5. Software. Muscle mass was calculated using Matiegka equation (Matiegka, 1921). Measurements of electrical bio-impedance were performed with the help of the device TANITA TBF-105. Measurements of body weight, body mass index, lean body mass, the percentage of fat mass, absolute fat mass and the percentage of body water were measured.

\section{RESULTS}

The values of the variables are shown in mean, standard deviation minimum and maximum. Table I shows the general and body composition characteristics. Table II shows anthropometrical characteristics of the unit. In Table III the somatotype components of the unit are shown. The data show that the special police unit overall presented the balanced mesomorph somatotype (2.59-6.49-1.98).
A graphical description of individual values of somatotype for the member of the police unit with the mean somatotype value is shown in Figure 1. In the special police unit $53 \%$ of the members were classified as endomorphicmesomorphs, $29 \%$ as balanced mesomorphs, and $18 \%$ were classified as ectomorphic-mesomorphs, respectively (Fig. 2).

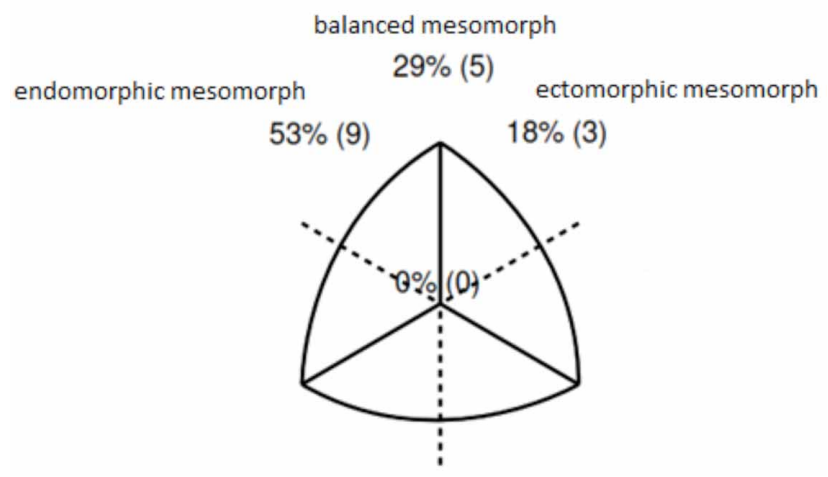

Fig. 1. Somatoplot distribution of special police unit

\section{DISCUSSION}

Recognition of somatotype is of high importance for people that work in special conditions as it describes the physical form in general and gives us a necessary answer for questions related with the specific conditions, demands and adaptation of the body.

The data shows that special police units should present the characteristics of balanced mesomorph with emphasis on mesomorphic component. Study by Santos \& Fernandes Filho (2007) done on the members of special military police units BOPE (3.24-5.91-1.72) confirms the necessity of the mesomorph component dominance as well as the study done by Simenko et al. (2016), on police special units (2.6-5.442.06). This information gives us an inside of the importance of the muscle mass which is essential component of producing

Table I. Mean, standard deviation, minimum and maximum of general and body composition characteristics of special police unit $(n=17)$.

\begin{tabular}{lcccc}
\hline Basics & Mean & Std. Deviation & Minimum & Maximum \\
\hline Height $(\mathrm{cm})$ & 179.46 & 5.36 & 169.00 & 190.10 \\
Weight $(\mathrm{kg})$ & 79.84 & 6.16 & 68.00 & 89.30 \\
BMI $(\mathrm{kg} / \mathrm{m})$ & 24.78 & 1.53 & 22.00 & 27.90 \\
\hline Body composition & & & & \\
\hline Muscle mass $(\mathrm{kg})$ & 44.02 & 3.72 & 38.00 & 52.10 \\
Fat mass $(\mathrm{kg})$ & 7.95 & 1.92 & 4.50 & 11.60 \\
Fat mass $(\%)$ & 9.86 & 2.18 & 5.70 & 13.50 \\
Lean body mass $(\mathrm{kg})$ & 72.69 & 4.85 & 60.80 & 81.40 \\
Total body water $(\%)$ & 53.21 & 3.56 & 44.50 & 59.60 \\
\hline
\end{tabular}


Table II. Mean, standard deviation, minimum and maximum of general anthropometrical characteristics of special police unit $(n=17)$.

\begin{tabular}{|c|c|c|c|c|c|}
\hline \multicolumn{2}{|l|}{ Variables } & Mean & SD & Minimum & Maximum \\
\hline \multirow{6}{*}{$\stackrel{\widehat{\Xi}}{\Xi}$} & Upper arm & 32.88 & 3.25 & 26.00 & 37.40 \\
\hline & Flexed upper arm & 38.31 & 5.37 & 32.70 & 57.30 \\
\hline & Forearm & 29.35 & 1.13 & 26.00 & 30.80 \\
\hline & Thigh & 59.83 & 2.22 & 55.00 & 64.70 \\
\hline & Mid-thigh & 57.54 & 2.13 & 52.10 & 61.60 \\
\hline & Calf & 40.18 & 1.80 & 36.80 & 43.30 \\
\hline \multirow{2}{*}{ Breadths $(\mathrm{cm})$} & Shoulder & 41.08 & 1.90 & 37.30 & 43.70 \\
\hline & Pelvic & 27.75 & 1.53 & 25.60 & 30.10 \\
\hline \multirow{4}{*}{ 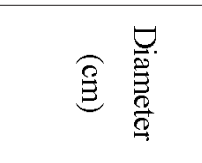 } & Elbow & 7.33 & 0.39 & 6.60 & 7.80 \\
\hline & Wrist & 5.89 & 0.28 & 5.30 & 6.30 \\
\hline & Knee & 9.94 & 0.41 & 9.20 & 10.60 \\
\hline & Ankle & 7.34 & 0.46 & 6.60 & 8.30 \\
\hline \multirow{9}{*}{ 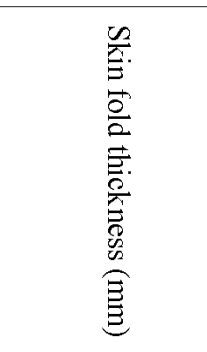 } & Subscapular & 11.52 & 2.71 & 7.60 & 17.60 \\
\hline & Triceps & 5.62 & 1.62 & 3.20 & 10.00 \\
\hline & Biceps & 3.64 & 0.96 & 2.20 & 6.00 \\
\hline & Forearm & 4.49 & 0.77 & 3.60 & 6.00 \\
\hline & Abdomen & 13.67 & 4.89 & 7.60 & 24.20 \\
\hline & Chest & 8.55 & 3.50 & 5.40 & 20.00 \\
\hline & Supraspinale & 10.01 & 2.72 & 5.40 & 16.20 \\
\hline & Thigh & 11.25 & 3.29 & 7.40 & 18.20 \\
\hline & Calf & 6.27 & 1.82 & 4.20 & 9.20 \\
\hline
\end{tabular}

Table III. Mean, standard deviation, minimum and maximum of somatotype components of special police unit $(\mathrm{n}=17)$.

\begin{tabular}{ccccc}
\hline Variable & Mean & SD & Minimum & Maximum \\
\hline ECTO & 1.98 & 0.68 & 0.90 & 3.30 \\
MESO & 6.49 & 0.87 & 4.20 & 8.20 \\
ENDO & 2.59 & 0.59 & 1.70 & 3.90 \\
\hline SAD & 1.03 & 0.66 & - & -
\end{tabular}

SAD- somatotype attitudinal distance.

strength, power and speed in dangerous work conditions. In special police forces the ectomorph component should not be very predominant, because the policemen should have a low mean stature, which is best for group movements of officer's body during combat between alleys, streets and buildings (Santos \& Fernandes Filho).

The importance of obtained data regarding the identification of somatotype requirements is to be used as descriptive comparative and selection parameter for/with other branches or units inside of the police. Specific work conditions difer greatly when compared to a general police officers which can be seen directly in the load carriage of basic tactical equipment of police special units, which weighs $21.15 \mathrm{~kg}$ (Simenko et al.). Study on the regular police officers from Turkey shows that they present lower mesomorphic component

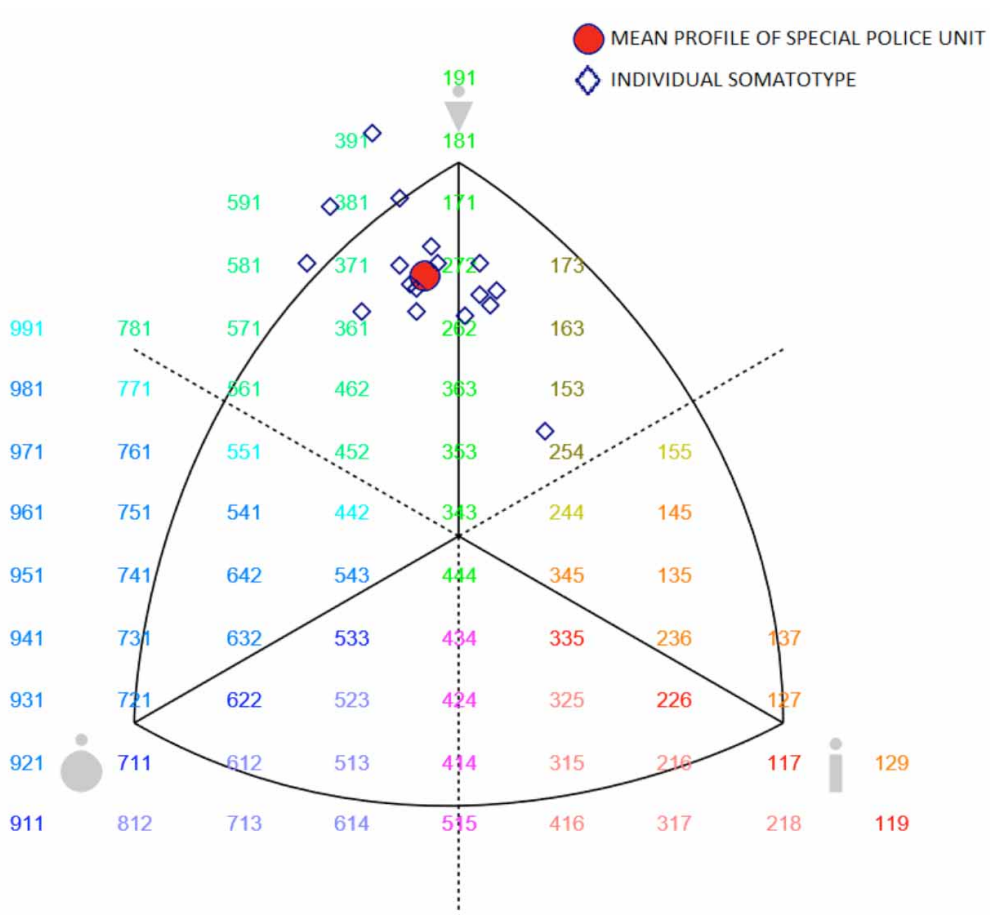

Fig. 2. Somatotype profile distribution of special police unit 
(2.67-4.59-2.96) and as previously mentioned, not so desired higher ectomorphic component (Özkan et al., 2012).

Special police officers, when compared to different sport disciplines in somatotype values, have the most similar characteristics with Brazilian jiu jitsu fighters (2.23-6.33-1.75) (Báez et al., 2014), judokas (1.87-6.57-1.79) (Stachon et al., 2015) and wrestlers (2.0-6.6-1.2) (Sterkowicz-Przybycien $e t$ al., 2011). This information can also give us an important information about strength and conditioning of special units which can be based on previously mentioned martial arts and combat sports with additional technical and tactical training including firearms, tactical team movement, breaching hostage rescue. With good selection of candidates and superior training programs, a good working environment can be created which increases operational performance of police special units.

SIMENKO, J. Perfil de somatotipo de una unidad especial de policía. Int. J. Morphol., 36(4):1225-1228, 2018.

RESUMEN: El propósito de este estudio fue investigar las características especiales del somatotipo de unidades especiales de la policía para otorgar una mejor idea acerca de los requisitos de la composición corporal y el somatotipo para el entrenamiento y el proceso de selección de los nuevos candidatos. Por lo tanto, se realizó un análisis antropométrico en 17 miembros masculinos de la unidad especial de la policía Eslovena con una edad media de $31,12 \pm 5,61$ años, altura corporal 179,46 $\pm 5,36$ $\mathrm{cm}$ y peso corporal $79,84 \pm 6,16 \mathrm{~kg}$. Fueron evaluados con variables antropométricas de acuerdo con ISAK. Se tomaron las siguientes medidas: circunferencia del brazo, circunferencia del brazo flexionado, circunferencia del muslo, circunferencia media del muslo, circunferencia de la pantorrilla, ancho del hombro, ancho de la pelvis, diámetro del codo, diámetro de la muñeca, diámetro de la rodilla, diámetro del tobillo, doblez de la piel subescapular, doblez de la piel del tríceps, doblez de la piel del bíceps, doblez de la piel del antebrazo, doblez de la piel del abdomen, doblez de la piel del tórax, doblez de la piel supraespinal, doblez de la piel del muslo y doblez de la piel de la pantorrilla. Además, la impedancia bioeléctrica TANITA TBF-105 se utilizó para realizar las siguientes mediciones: peso corporal, índice de masa corporal, masa corporal magra, porcentaje de masa grasa, masa grasa absoluta y el porcentaje de agua corporal. Los componentes del somatotipo y la posición en el somatoplot se calcularon con el Software Somatotype 1.2.5. Los valores encontrados en este estudio indican una importancia significativa del componente mesomorfo para las unidades especiales de la policía y su naturaleza de trabajo con el dominio del somatotipo mesomorfo balanceado $(2,59-6,49-1,98)$.

\section{les tácticos.}

PALABRAS CLAVE: Morfología; Antropometría; Oficia-

\section{ACKNOWLEDGMENTS}

The author is grateful to Senior Lecturer Bojan Zorec for his assistance and collaboration in the sample collection and to Prof. Dr. Milan Coh for his constant support.

\section{REFERENCES}

Báez, E.; Franchini, E.; Ramírez-Campillo, R.; Cañas-Jamett, R.; Herrera, T.; Burgos-Jara, C. \& Henríquez-Olguín, C. Anthropometric characteristics of top-class Brazilian jiu jitsu athletes: role of fighting style. Int. J. Morphol., 32(3):1043-50, 2014.

Carter, J. E. \& Heath, B. H. Somatotyping. Development and applications. New York, Cambridge University Press, 1990.

Claessens, A. L.; Beunen, G. \& Malina, R. M. Anthropometry, Physique, Body Composition and Maturity. In: Armstrong, N. \& Van Mechelen, W. (Eds.). Paediatric Exercise Science and Medicine. 2nd ed. Oxford, Oxford University Press, 2000. pp.23-36.

Gorenak, V.; Krope, S. \& Tanasic, M. Evropske Specialne Policijske Enote. Ljubljana, Fakulteta za varnostne vede, 2007.

Malina, R. M. Body composition in athletes: assessment and estimated fatness. Clin. Sports Med., 26(1):37-68, 2007.

Matiegka, J. The testing of physical efficiency. Am. J. Phys. Anthropol., 4(3):22330, 1921.

Ochoa Martínez, P. Y.; Hall López, J. A.; Alarcón Meza, E. I.; Arráyales Millán, E. M. \& Sánchez León, R. Somatotype profile and body composition of players from the Mexican professional basketball league. Int. J. Morphol., 32(3): 1032-5, 2014.

Özkan, A.; Kayihan, G.; Köklü, Y.; Akca, F.; Eyüpog `lu, E.; Koz, M. \& Ersöz, G. An examination of some physical fitness and somatotype characteristics of Turkish national police. J. Hum. Sci., 9(1):271-82, 2012.

Rodrigues-Ferreira, M. A.; VencesBrito, A. M.; Mendes, J.; Fernandes, R. \& Fernando, C. Changes inbody composition after 6 months of training in pubertal swimmers. Int. J. Morphol., 33(1):350-4, 2015.

Santos, M. R. \& Fernandes Filho, J. Profile study od dermatoglyphics, somatotypical and physical qualities of Bopes's team (PMERJ) in year 2005. Fit. Perform. J., 6(2):98-104, 2007.

Simenko, J.; Skof, B.; Hadzic, V.; Milic, R.; Zorec, B.; Zvan, M.; Vodicar, J. \& Coh, M. General and specific physical abilities of the members of special police unit. Facta Univ. Ser. Phys. Educ. Sport, 14(1):83-98, 2016

Slater, G.; Woolford, S. M. \& Marfell-Jones, M. J. Assessment of Physique. In: Tanner, R. K. \& Gore, C. J. (Eds.). Physiological Tests for Elite Athletes. $2^{\text {nd }}$ ed. Champaign, Human Kinetics, 2013. pp.167-98.

Stachon, A.; Burdukiewicz, A.; Pietraszewska, J. \& Andrzejewska, J. A comparative analysis of male judo and Brazilian jiu-jitsu practitioners based on motor performance and body build. J. Combat Sports Martial Arts, 6(2):53-8, 2015.

Sterkowicz-Przybycien, K. L.; Sterkowicz, S. \& Zarów, R. T. Somatotype, body composition and proportionality in polish top greco-roman wrestlers. $J$. Hum. Kinet., 28:141-54, 2011.

Yao, Z.; Yuan, Y.; Buchanan, T. W.; Zhang, K.; Zhang, L. \& Wu, J. Greater heart rate responses to acute stress are associated with better post-error adjustment in special police cadets. PLoS One, 11(7):e0159322, 2016.

Zorec, B. Anthropometric characteristics in police officers. J. Crim. Justice Secur, 11(1):26-35, 2009.

Corresponding author:

Jozef Simenko

Institute of Sport

Faculty of Sport

University of Ljubljana

Gortanova 22, 1000 Ljubljana

SLOVENIA

Email: jozefsimenko@gmail.com
Received: 08-03-2018

Accepted: 27-06-2018 